\title{
Funds for professional activities
}

\author{
By Jacqueline M. Morris \\ Chair, ACRL Professional Association Liaison Committee
}

\section{Liaison activities are eligible for ACRL funding.}

$\mathbf{T}$ he ACRL Professional Association Liaison Committee (PALC) has been exploring methods of strengthening ACRL's relationships with other professional associations.

For the past several years the committee has been awarding grants to individual members for their activities with a wide variety of associations. In the March 1988 C $\& R L$ News, pp. 152-55, Danielle Mihram describes her participation in the Modern Language Association's annual program in her article, "Online Databases and Book Preservation" Mihram's attendance was made possible in part by a grant from ACRL's PALC.

Another member whose liaison activity was supported by PALC was Elizabeth Hanson, Indiana University. She attended the 1987 Biennial Conference of the Association for Canadian Studies in the United States (ACSUS), in Montreal, October $7-10,1987$, and reports:

"I presented a paper entitled 'The Development of English-language Libraries in Montreal, 1840-1940.' It discussed the three libraries that sought to provide general library services to the English-speaking population during that time, with emphasis on the reasons for their establishment and the collections, facilities and services they offered.

"I feel that my participation in the ACSUS Conference was beneficial in a number of ways. The arrangement of the conference encouraged considerable interaction among the attendees, most of whom were teaching faculty from American colleges and universities. A number of the participants with whom I spoke had not previously been aware of the wide range of activities in which academic librarians are involved. I feel that our discussions prompted them to realize that they shared many interests with their colleagues in university and college libraries.

"On my part, as a cataloger I have only limited contact with teaching faculty and it was very helpful to hear what resources the participants found useful and how they went about locating information. In addition, the book exhibits made me more knowledgable about current resources in Canadian studies.

"Finally, I feel that ACSUS was very pleased with the contributions made by the librarians who attended and participated in the conference. As a result, the 1989 Biennial Conference may include a larger library-oriented session.

"I feel that as an academic librarian my involvement with the ACSUS Biennial Conference was very productive and I am grateful for the support which the ACRL Professional Association Liaison Committee provided. I would encourage other librarians to become involved in non-library professional organizations related to their interests; it promises to be an exciting and rewarding experience."

ACRL encourages and solicits applications for liaison activities. You may use the following procedures to apply for financial support. If you are interested in obtaining such a grant, applications must be received by June 30, 1988 .

\section{Procedures for distribution of funding to membership for liaison activities}

\section{Purpose:}

A nominal amount of money has been set aside by ACRL to support membership liaison activities in other (non-library) professional associations. 
The ACRL Professional Association Liaison Committee invites proposals for funding and uses the following guidelines for distribution of financial support.

\section{Criteria:}

1. Support for participation in organizations could include activities such as major presentations, panel discussions, poster sessions, publications of articles and more. In awarding the funding request, the committee will give weight to the significance of the contribution.

2. Preference will be given to efforts which contribute to the understanding or use of academic library resources or services. Also eligible for funding are efforts which enhance the perception of academic librarians as part of "the education team."

3. Must be an ALA member, with preference given to ACRL members.

4. Adequate documentation must be provided and should include all points listed in the format suggested below.

\section{Methods:}

1. Funding will be up to $\$ 300$ of costs not covered by others for travel, accommodations, and registration (not membership).

2 . There is no limit on the number of grants that may be awarded to an individual.

3. Funding will be awarded after the event, but requests may be submitted for approval prior to the event. Awards are dependent on the committee receiving a report of activity.

4 . The committee may request information suitable for publication within six months after the event.

5. The committee meets twice a year to review applications: at ALA Midwinter and Annual Meetings.

Please send applications to: Jacquelyn M. Morris, Chair, ACRL Professional Association Liaison Committee, Mary Norton Clapp Library, Occidental College, 1600 Campus Road, Los Angeles, CA 90041.

\title{
Strategic planning for ACRL
}

\author{
By the ACRL Planning Committee
}

Carolyn Dusenbury, Chair

\section{The annual report of ACRL's Planning Committee.}

T his is the first of a series of annual Strategic Planning reports to the ACRL membership. Because the planning process is still relatively new to the Association, this report provides an overview the ACRL Strategic Plan, describes briefly how the planning process operates, and attempts to answer some of the most frequently asked questions.

\section{Overview}

The ACRL Strategic Plan is the result of six years of work by two ACRL task forces, the Task Force on an Activity Model for the 1990's (1980-1982) and the Strategic Planning Task Force (1984-1986). To aid in the development of the plan, a large-scale needs assessment was conducted by mail and the plan was the focus of the $1985 \mathrm{An}$ nual Membership meeting. Membership involvement was crucial in establishing both the directions and goals of ACRL.

The Strategic Plan consists of several parts: a mission statement, four broad goals (e.g., "To contribute to the total professional development of academic and research librarians"), with subgoals for each goal (e.g., "To sponsor and encourage opportunities for...librarians to update existing compe- 